\author{
Ihor Bloshchynskyi, \\ Doctor of Pedagogy, associate professor, \\ professor of the English Language Department, \\ National Academy of the State Border Guard Service \\ of Ukraine named after Bohdan Khmelnytskyi, \\ 48, Shevchenka Str., Khmelnytskyi, Ukraine
}

\title{
ENHANCEMENT OF CADETS' PRACTICAL TRAINING AT THE NATIONAL ACADEMY OF THE STATE BORDER GUARD SERVICE OF UKRAINE NAMED AFTER BOHDAN KHMELNYTSKYI
}

Considering the difficult situation in the country and the need for protection and defense of the southeastern border of Ukraine, the role of professional training of future border guard officers, particularly its practical component, is extremely important today. Therefore, the article reveals the peculiarities of cadets' practical training at The National academy of the State Border Guard Service of Ukraine named after Bohdan Khmelnytskyi majoring in "State Border Security", "Law enforcement activity", "Philology", "Psychology", "Automobile transport" and "Telecommunications" at the Bachelor's level. Enhancement of cadets' practical training for the Seniors is implemented and conducted at the following departments of the academy: border guard service tactics; border control; combined subjects; personal security; constitutional, administrative and international law; engineering and technical means of border protection. The implementation of trainings simulating practical actions (general military, military-engineering, fire and medical trainings; courses on border control, border guard service tactics, personal security, administrative proceedings) contributes to cadets' practical skills mastering and professional training 's practical component improvement.

Keywords: enhancement of practical training; trainings; future border guard officers.

\section{Introduction}

The requirements to the professional training of future border guard officers are severed due to the reforming of the the State Border Guard Service of Ukraine (SBGSU), development of new forms and ways of state border protection, introduction of modern information technologies (IT) of teaching. It stipulates a qualitatively new approach to their vocational training as the educational process at the National academy of the State Border Guard Service of Ukraine named after Bohdan Khmelnytskyi (NASBGSU) is demanding, changeable and complex. Service at the state border of Ukraine makes special demands for the personnel of border guard protection units and motivates them constantly to support and improve their professional competence. Therefore, the role of professional training, particularly its practical component is extremely important for modern Ukraine.

Various issues of personnel training at border guard educational establishments of European countries, USA, China and others are studied by many foreign and Ukrainian researchers. For example, A. Balendr investigated modern standards of training and retraining of managerial officers of Hungarian border guards [1], N. Ryndenko considered communicative training trends of cadets at Border Guard of the Republic of Poland, [2] E. Komkova researched American-Canadian integration [3], H. Kang performed the comparative analysis of state policies on higher education in the USA and in the PRC [4]; L. Rongzheng explored Chinese ideological training of border guards in China [5]; X. Hao, L. Yin-shan examined optimization of the educational process at Chinese border guard educational establishments [6].

Personnel training at higher military educational establishments (HMEEs) and peculiarities of professionally significant qualities formation of SBGSU personnel have been investigated by A. Belorus (information culture formation of future border guard officers) [7], P. Vishniewski (pedagogical management improvement in the educational process at HMEEs based on innovative technologies) [8], B. Zelenyi (pedagogical culture development of junior officers of internal troops in Ukraine) [9].

However, despite considerable interest of researchers to this issue, the aspects of strengthening practical component in training future border guard officers still remain understudied.

Taking the foregoing into account, the aim of the paper is to describe the peculiarities of cadets' practical training at border guard units as well as training courses conducted for enhancement of the practical component of future border guard officers' training.

\section{Discussion}

The National academy of the State Border Guard Service of Ukraine named after Bohdan Khmelnytskyi (NASBGSU) is at the top in officers' training among other borderguard educational institutions and centres in Ukraine. It consists of administration, five faculties, personnel further training center, postgraduate military course, doctoral studies, training control and support units.

The Academy provides two-level system of training: the first (Bachelor) level of higher education in the specialties "State Border Security", "Law enforcement activi- 
ty", "Philology", "Psychology", "Automobile transport" and "Telecommunications"; and the second (Master's) level of higher education.

Considering the complex situation in the country and experience of the protection and defense of the southeastern border areas of the state, new models of cadets training based on practical execution of law enforcement and military objectives were developed; basic qualifications for graduates were corrected. In view of this, $2 / 3$ of the teaching hours are allocated to the study of professionally oriented subjects, $70 \%$ of which are practical classes.

Target reorientation on practical learning content (the military part) within the law-enforcement function of the border agency was performed. Practical component increasing is based on the experience of combat employment of border units in a rapid change of the situation and localization of conflict, non-standard situations at the state border, combating sabotage-reconnaissance groups and illegal military formations.

Cadets' practical training at the NASBGSU is performed in order to enrich and improve knowledge acquired during lectures, and to improve practical skills in performing duties in border guarding units under real conditions. The main objectives of cadets' practical training are as follows: educational process efficiency improvement; interrelation between the theory and practice, operative implementation of practical activities experience of border guard units into educational process; improvement of professional knowledge and practical skills in specialities on corresponding positions in border guard units; generalization of practical activities results of academy graduates, analysis of their adaptation to the conditions of operative and service activities [10].

Practical training types for cadets in each speciality (specialization), their forms, duration and terms of execution are determined in the academic curricula. There are the following main types of practice for cadets in the academy: introductory practice intended for primary acquaintance with different sorts of practical activities in the selected speciality; educational training which is conducted as a part of extracurricular activities by engaging cadets into certain work under the selected speciality in corresponding organizations; field training which is a completion phase of training and it is conducted after mastering the theoretical part and is aimed at obtaining practical training of future specialists for independent accomplishment of professional functions on a certain position or in a professional activity sphere [11].

Educational practice is conducted in corresponding specialities in order to acquire practical skills in courts, offices of Public Prosecutor and other legal (lawenforcement) institutions; comprehensive schools and other educational establishments; enterprises, organizations of all ownership forms; auto repair units of the SBGSU, plants of the military industrial complex, etc.

Field training is conducted in order to gain and develop knowledge and skills in carrying out duties of border guard officials, to acquire and deepen practical skills under real conditions at the border. Field training is basically conducted on posts similar to primary assignments of cadets in border guard units according to requests of the academy and orders of the SBGSU.

During the field training in border guard units at the first and second years of studying cadets take part in the work of the shift supervisor of border details (assistant of the shift supervisor of border details); preparation of the shift of border details for service; the service on state border protection; control over the service of border details at the sector of a border guard division and in a border crossing point; control over regime in a border crossing point; drawing up of documents on border-related violations. As a whole, cadets acquire necessary practical skills in organization of operative and service activities of border guard units, take part in practical service of different types of border details. Unlike the first two years of studying at the Academy, field training during the third year, in particular, is characterized as the "entrance" of cadets in the profession of border guard officer. Intensive military and educational development of an individual, direct participation in the organization and execution of operative and service activities promote not only interest in the profession, but also contribute to practical readiness to carry out professional duties. Field training of future border guard officers of the fourth year of study is conducted at border guard units taking into consideration the specificity of their specialty. For example, if cadets major in "State border security" then their post is the chief (deputy chief) of inspector's section at a border guard division. A graduate cadet not only realizes the personal sense of his occupation, but also is prepared for accomplishment of his professional duties.

Cadets of the academy take field training in border guard units, educational centers under command of officers of border guard units, educational center and under the supervision of academy training supervisor. The methodical management of preparation for the field training of cadets is carried out by faculties and graduate departments. In order to organize and carry out field training of cadets a working group is created according to an order of the rector of the academy. It comprises supervising instructors and the commanding staff of faculties and training courses.

In order to improve the organization and carrying out of field training of the future border guard officers a number of steps should be taken. The preparation of training supervisor from the academy involves studying the directive documents, preparation of educational materials, development of a work plan, solving the problems of sending and travelling of cadets to the place of field training. The command of a training course organizes preparation for the field training of the future officers. While getting ready for the field training the cadets independently study methodical recommendations concerning the organization and carrying out of field training. They learn the content of the lessons conducted by them personally; personal participation in the management of daily and 
service activities; list of functional duties of the would-be post; orders, other directive documents which concern their field training. Individual tasks for cadets are developed at the departments according to the program of field training and are approved by the academy training supervisors. In order to improve the organization and carrying out of field training of the future border guard officers they keep the Field Training Journal where all organized and executed activities are recorded. It contains the following sections: general instructions; tasks according to the field training programs; individual tasks for field training; a working plan of a cadet for field training; a field training record card; a report of a cadet on executed tasks during field training [10].

Officers of the border guard units make reports to estimate the results of cadets' activities during the field training. A typical report covers the estimation of professional, individual professionally important psychological qualities of the cadet; the accomplishment of the individual tasks; the characteristic lacks in the training; the proposals of the command of the border guard unit concerning improvements of professional training of cadets. Cadets study individual tasks and the order of keeping daily records on their field training. After the arrival to a field training place, studying of the order and organization of service activities, peculiarities of service, the daily plan and lesson schedule cadets make the working plan for the whole period of field training, adjust it with the academy training supervisor and submit for approval to the chief of the border guard unit where the field training is to be conducted.

After finishing field training, the chief of the border guard unit where the cadet did field training makes records in his journal personally about the results of his field training. The chief makes conclusions on the completeness and quality of accomplishment of individual tasks by the cadet and determines the characteristic weaknesses in the training. He specifies propositions concerning the improvement of the cadets' training in the speciality and draws up a report according to the results of the cadet's activities. At the end of their field training cadets make a written report on accomplishment of their individual tasks and give it to the academy training supervisor for reviewing. The reports on cadets' field training written by the chief of the border guard unit where the cadets did field training are approved by chiefs of border detachments and together with the journals are submitted to the deanery of faculties after presenting the results of the field training at the leading departments.

Specific innovative training courses have been elaborated as a part of cadets' professional competence development. Some training courses simulating practical actions were developed for the graduates of 2016-2017 (general military, military-engineering, fire and medical trainings; courses on border control, border guard service tactics, personal security, administrative proceedings).

Considering the improvement of practical training of the cadets at the border guard academy, practical 45- minute classes for the Seniors are conducted during the first hour of independent study (14.55-15.40) at the following departments of the academy:

Department of border guard service tactics. Purpose of training: improving the skills of the cadets of the 4th year of studying for taking certain decisions during execution of tasks of state border guarding. Training tasks: prepare cadets for actions in combat engagements and in cases of situational complications during protection of certain state border sector. Frequency of training: monthly.

Department of border control. Purpose of the training: updating and deepening of knowledge in the field of border control, detailed study of new regulations governing service activities of state border guard units on international traffic routes. Training tasks: acquisition of practical border control skills. Frequency of training: fortnightly.

Department of combined subjects:

1. Topography. Purpose of the training: improving graduate cadets' skills of working with the commander's map. Training tasks: acquisition of practical skills in terms of measuring angles and coordinates of points on the map, drawing of symbols. Frequency of training: monthly.

2. Radiation, chemical and biological protection of units. Purpose of the training: improving practical skills in use of personal protection equipment and actions under the conditions of radioactive, chemical and biological contamination. Training tasks: teach cadets how to use personal protection equipment and correct course of actions under the conditions of radioactive, chemical and biological contamination. Frequency of training: monthly.

3. Military Engineering Training. Purpose of the training: to provide basics of mine safety. Training tasks: to teach cadets how to identify dangerous explosive items and train them how to act afterwards. Frequency of training: monthly.

Department of personal security. Purpose of the training: acquiring practical skills in preparation for combat use and maintenance of small arms and grenade launchers, combat means of border units' augmentation, fire adjustment and improving skills of physical coercion and use of special means while performing operational and service tasks. Frequency of training: monthly.

Department of constitutional, administrative and international law. Purpose of the training: improving practical skills of border personnel in the drafting of procedural documents of proceedings in cases of administrative offenses. Frequency of training: monthly.

Department of engineering and technical means of border protection. Purpose of the training: acquiring practical skills while working with technical means of border protection. Training tasks: learning to choose the site for installing technical means of border protection and getting them ready for operation; check their efficiency; conduct border surveillance with the help of technical means. Frequency of training: fortnightly. 
The training courses take place 3-4 times a week, 45 minutes each during the first hour of independent study. As a result, several additional training hours were added to the course of training aimed at knowledge and skills acquisition by the cadets as a part of practical implementation of military academic components.

In addition, in order to increase and improve the practical component of the educational process, the following measures are implemented:

- role playing games concerning the issues of border details service at checkpoints across the state border; border control technologies; compliance with departmental standards of culture of border control at checkpoints; personnel actions during the localization of nonstandard situations at checkpoints;

cooperation with Khmelnytskyi center of customs officers' training and retraining, where the complex practical training on the issues of border and customs clearance of vehicles movement abroad are conducted; Khmelnitsky railroad passenger station, where combined workshops, aimed at forming professional competence on border procedures at border control are held.

As innovation, in order to improve the practical training of cadets on detection of stolen motor vehicles at the Research Forensic Center of the Ministry of Internal Affairs of Khmelnitsky region and the police department of registration and examination, practical lessons on the

\section{REFERENCES}

1. Balendr, A. V. (2013). Suchasni standarty pidhotovky ta perepidhotovky ofitseriv upravlinskoi lanky prykordonnoi sluzhby Ugorshchyny [Modern standards of training and retraining of managerial officers of Hungarian border guards]. Visnyk Natsionalnoho universytetu Oborony Ukrainy - Journal of National University of Defense of Ukraine, 5(36), 7-12. Kyiv: NUOU [in Ukrainian].

2. Ryndenko, N. M. (2016). Tendencii komunikatyvnoi pidhotovky kursantiv navchalnykh zakladiv Prykordonnoi varty Respubliky Polshchi [Communicative training trends of cadets at Border Guard of the Republic of Poland]. Candidate's thesis. Khmelnytskyi: NADPSU [in Ukrainian].

3. Komkova, E. H. (2008). Novyi etap amerykanokanadskoi intehracii [New stage in American-Canadian integration]. USA - Kanada: ekonomika, politika, kultura - USA-Canada: economics, policy, culture, 5, 15-30 [in Russian].

4. Haijun Kang. (2009). A comparative study of the distance education history in China and the United States: a socio-historical perspective. A Dissertation in Adult Education and Comparative \& International Education. Candidate's thesis. The Pennsylvania State University [in English].

5. Liu Rong-zheng. (2014). On Ideological Education of Border-control Forces of Public Security Guided by Service Function. Journal of Chinese People's Armed Police Force Academy, 11, 53-56 [in English]. topic "Identifying stolen motor vehicles" as a separate component of border control are conducted involving relevant experts.

\section{Conclusions}

Thus, field training in border guard units of the SBGSU has its peculiarities of professional competence formation, definite purposes, peculiar forms and methods. Enhancement of cadets' practical training simulating practical actions (general military, military-engineering, fire and medical trainings; courses on border control, border guard service tactics, personal security, administrative proceedings) were introduced at the border guard academy for the Seniors; implemented and conducted during the first hour of independent study at the following departments of the academy: border guard service tactics; border control; combined subjects; personal security; constitutional, administrative and international law; engineering and technical means of border protection. Thus, by means of introduction of trainings, educational practice, field training, role plays cadets' practical skills are being mastered, as well as the practical component of education and professional training programs is being improved.

It is planned to elaborate recommendations for the teaching staff of NASBGSU as for practical component improvement in future border guard officers' professional training.

6. Xiao Hao, Liu Yin-shan. (2015). On Optimizing the Identity Education Environment of the Chinese Dream for the Young Officers and Soldiers of Border-control Forces of the Public Security. Journal of Chinese People's Armed Police Force Academy, 3, 30-34 [in English].

7. Bilorus, A. M. (2007). Pedahohichni umovy formuvannia informaciinoi kultury $u$ maibutnikh ofitseriv-prykordonnykiv [Information culture formation of the future border guard officers]. Extended abstract of candidate's thesis. Khmelnytskyi: NADPSU [in Ukrainian].

8. Vyshnevskyi, P. R. (2005). Udoskonalennia pedahohichnoho upravlinnia navchalnym protsesom $\mathrm{u}$ vyshchomu viiskovomu navchalnomu zakladi na osnovi innovaciinykh tekhnolohii [Pedagogical management improvement of educational process at higher military educational establishments based on innovative technologies]. Candidate's thesis. Khmelnytskyi: NADPSU [in Ukrainian].

9. Zelenyi, V. I. (2008). Rozvytok pedahohichnoi kultury molodykh ofitseriv vnutrishnikh viisk MVS Ukrainy [Pedagogical culture development of junior officers of internal troops of Ukraine]. Extended abstract of candidate's thesis. Khmelnytskyi: NADPSU [in Ukrainian].

10. Polozhennia z orhanizatsii ta provedennia praktychnoi pidhotovky kerivnoho, naukovo-pedahohichnoho skladu, slukhachiv, kursantiv ta studentiv Nacionalnoi akademii Derzhavnoi prykordonnoi sluzhby Ukrainy 
imeni Bohdana Khmelnytskoho [Instruction on the organisation and conducting of practical training of command, teaching staff, cadets and students at the National academy of the State border guard service of Ukraine named after Bogdan Khmelnytskyi]. (2015). Approved by the order of rector of NASBGSU № 117 of 05/06/2015. Khmelnytskyi: NADPSU [in Ukrainian].

\section{ЛІТЕРАТУРА}

1. Балендр А. В. Сучасні стандарти підготовки та перепідготовки офіцерів управлінської ланки прикордонної служби Угорщини / А. В. Балендр // Вісник Національного університету Оборони України : зб. наук. праць. - К. : НУОУ, № 5(36)/2013. - К., 2013. C. 7-12.

2. Ринденко Н. М. Тенденції комунікативної підготовки курсантів навчальних закладів Прикордонної варти Республіки Польща : дис. ... канд. пед. наук : 13.00.04 / Наталія Миколаївна Ринденко. Хмельницький, 2016. - 212 с.

3. Комкова Е. Г. Новый этап американоканадской интеграции / Е. Г. Комкова // США - Канада: экономика, политика, культура. - 2008. - № 5. C. $15-30$.

4. Haijun Kang. A comparative study of the distance education history in China and the United States: a socio-historical perspective. A Dissertation in Adult Education and Comparative \& International Education. Submitted in Partial Fulfillment of the Requirements for the Degree of Doctor of Philosophy. 2009. - The Pennsylvania State University. - 205 pages.

5. Liu Rong-zheng. On Ideological Education of Border-control Forces of Public Security Guided by Service Function. Journal of Chinese People's Armed Police Force Academy, 2014 (11). - P. 53-56.

6. Xiao Hao, Liu Yin-shan. On Optimizing the Identity Education Environment of the Chinese Dream for the Young Officers and Soldiers of Border-control Forces

11. Polozhennia pro orhanizatsiu osvitnoho procesu $v$ NADPSU [Instruction on the organisation, planning and conducting of educational process at the NASBGSU]. (2015). Approved by the order of rector of NASBGSU № 221 of 30/11/2015). Khmelnytskyi: NADPSU [in Ukrainian].

the Public Security. Journal of Chinese People's Armed Police Force Academy, 2015 (03). - P. 30-34.

7. Білорус А. М. Педагогічні умови формування інформаційної культури у майбутніх офіцерівприкордонників : автореф. дис. на здобуття наук. ступеня канд. пед. наук : 13.00.04 / Андрій Миколайович Білорус. - Хмельницький, 2007. - 21 с.

8. Вишневський П. Р. Удосконалення педагогічного управління навчальним процесом у вищому військовому навчальному закладі на основі інноваційних технологій : дис. ... канд. пед. наук : 13.00.04 / Петро Ростиславович Вишневський. - Хмельницкий, 2005. - 205 c.

9. Зелений В. І. Розвиток педагогічної культури молодих офіцерів внутрішніх військ МВС України : автореф. дис. на здобуття наук. ступеня канд. пед. наук : спец. 13.00.04 «Теорія і методика професійної освіти» / В. І. Зелений. - Хмельницький, 2008. - 20 с.

10. Положення 3 організації та проведення практичної підготовки керівного, науково-педагогічного складу, слухачів, курсантів та студентів Національної академії Державної прикордонної служби України імені Богдана Хмельницького : наказ ректора НАДПСУ від 05.06.2015 № 117 / НАДПСУ. - 2015. - 50 с.

11. Положення про організацію освітнього процесу в НАДПСУ : наказ ректора НАДПСУ від 30.11.2015 № 221. - Хмельницький : Видавництво НАДПСУ, 2012. - 85 с.

Ігор Григорович Блощинський, доктор педагогічних наук, доиент, професор кафедри англійської мови, Національна академія Державної прикордонної служби України ім. Богдана Хмельницького, вул. Шевченка, 48, м. Хмельницький, Украӥна

\section{ПОСИЛЕННЯ ПРАКТИЧНОЇ ПІДГОТОВКИ КУРСАНТІВ У НАЦІОНАЛЬНІЙ АКАДЕМІЇ ДЕРЖАВНОЇ ПРИКОРДОННОЇ СЛУЖБИ УКРАЇНИ ІМЕНІ БОГДАНА ХМЕЛЬНИЦЬКОГО}

3 урахуванням складної обстановки в країні та необхідності охорони і оборони південно-східних ділянок державного кордону України, роль професійної підготовки майбутніх офіцерів-прикордонників, а особливо їі практичної компоненти на сучасному етапі набуває важливого значення. У зв'язку з цим у статті розкрито особливості проходження стажування в органах охорони державного кордону курсантів Національної академії Державної прикордонної служби України імені Богдана Хмельницького, які навчаються за спеціальностями «Безпека державного кордону», «Право та правоохоронна діяльність», «Філологія», «Психологія», «Автомобільний транспорт» та «Телекомунікації»; за першим (бакалаврським) рівнем підготовки вищої освіти. Особливу увагу приділено розробці та характеристиці проведення тренінгів для посилення практичної компоненти у підготовці майбутніх офіцерів-прикордонників, які було організовано із розрахунку 3-4 тренінги на тиждень тривалістю по 45 хвилин на 1-ій годині самостійної підготовки. В результаті було отримано певний обсяг навчальних годин, що надало можливість логічно та послідовно набувати курсантами впевнених знань, 
умінь і навичок в практичній реалізації складових військової компоненти. Для реалізації поставленої мети використано комплекс таких методів: теоретичні методи аналізу, синтезу, обгрунтування, узагальнення, систематизації теоретичного i практичного матеріалу дослідження. Посилення практичної підготовки курсантів, а саме впровадження тренінгів для курсантів випускного курсу здійснюється на таких кафедрах: тактики прикордонної служби; прикордонного контролю; загальновійськових дисциплін; особистої безпеки; конституційного, адміністративного та міжнародного права; інженерного забезпечення та технічних засобів охорони кордону. Із впровадженням тренінгів, з відпрацювання способів практичних дій (із загальновійськової, військово-інженерної, вогневої та медичної підготовки, прикордонного контролю, тактики прикордонної служби, особистої безпеки, адмінпровадження) отримано вдосконалення практичних навичок у курсантів випускних курсів і підвищення практичної компоненти професійної підготовки.

Ключові слова: посилення практичної підготовки, тренінги, майбутні офіцери-прикордонники, Україна.

Submitted on March, 6, 2017

UDC: $378.147:[373.5 .011 .3-051: 80]$

DOI: https://doi.org/10.24195/2414-4665-2017-4-2

Nataliia Siaska,

PhD (Candidate of Pedagogical Sciences), associate professor, Department of Foreign Language Teaching Methodology, Rivne State Humanitarian University, 31, Plastova Str., Rivne, Ukraine

\section{POETRY AS A MEANS OF DEVELOPING FUTURE TEACHERS-PHILOLOGISTS' SPEAKING SKILLS}

Nowadays teaching foreign languages to students is aimed at their mastering of intercultural communication in standard situations on the basis of communicative minimum including certain knowledge of linguistic and cultural studies. Proper attention should be paid to the selection of teaching material: it must be authentic, in our case - authentic poetry. The paper aims to describe the ways of improving students' practical readiness for oral communication, elicit potential of poetic texts and consider them as a means of enriching students'vocabulary based on reading and analysis. It will allow future foreign language teachers to improve their proficiency, prepare themselves for tolerant attitude towards other cultures and nations as well as comparing them with the specific character of their own culture, critical reflection of it and the system of personal values. Advancement of teaching English vocabulary is implemented through interactive teaching reading and understanding authentic poetry through the system of individual tasks. The latter are aimed at stimulation of reading authentic poetry by students, development of their abilities and skills of independent work on these tasks, raising the level of mastering foreign language vocabulary. Work with poetry may be used efficiently for the development of students' creative thinking as motivation for enrichment vocabulary with culturespecific words and for the development of spontaneous speech.

Keywords: intercultural communication, innovative method, authentic foreign language communication.

\section{Introduction}

In today's society, there is a challenging problem of training skilled personnel for every sphere of activity, including higher linguistic educational institutions. State documents on higher education place emphasis on the necessity to educate the new generation of teaching staff prepared for meeting educational needs of every personality, development of his/her intellectual and cultural potential. In this context, improvement of the efficiency of training future teachers of foreign languages becomes a topical issue of contemporary higher pedagogical education. Nowadays teaching foreign languages to students is aimed at their mastering of intercultural communication in standard situations on the basis of communicative minimum including certain knowledge of linguistic and cultural studies.
Besides, future philologists should be able to teach foreign literature and country studies [5]. The main purpose of teaching foreign languages to students of linguistic specialties is the formation of their communicative competence. The main strategic orientation of the English Curriculum for students of higher educational institutions is the formation of professional communicative competence.

With regard to the above-mentioned purposes, proper attention should be paid to the selection of teaching material: it must be authentic; in our case, it is reasonable to use authentic poetry. Authentic texts are those that are used in everyday life of native speakers, their real output, which is characterised by inartificial vocabulary, grammatical forms, usage of contextually appropriate means of a language [1]. 